\title{
Ownership Changes and Harvesting Patterns Associated with the Forest Products Industry in West-Central Alabama from 1984 to 2014
}

\author{
Seth Hunt ${ }^{1}$, Rebecca Barlow ${ }^{1}$, John Kush ${ }^{1}$, Larry Teeter ${ }^{1} \&$ Conner Bailey ${ }^{2}$ \\ ${ }^{1}$ School of Forestry and Wildlife Sciences, Auburn University, Auburn, Alabama, USA \\ ${ }^{2}$ School of Agricultural Economics and Rural Sociology, Auburn University, Auburn, Alabama, USA \\ Correspondence: Seth Hunt, School of Forestry and Wildlife Sciences, Auburn University, Auburn, Alabama, \\ United States of America. E-mail:Sdh0001@auburn.edu
}

Received: February 10, 2018

doi:10.5539/jsd.v11n4p53
Accepted: May 17, $2018 \quad$ Online Published: July 29, 2018

URL: https://doi.org/10.5539/jsd.v11n4p53

\begin{abstract}
Since the beginning of the 1980 s, vertically integrated forest products companies have divested their forestland with much of the new ownership being real estate investment trusts (REITs) and timberland investment management organizations (TIMOs). These new landowners and their associated behavior of intensive timber management and higher and better use conversion has given rise to issues such as land-use change, fragmentation, and conservation. To better gauge harvesting patterns and ownership changes associated with the divestment of forestland by forest industry and the arrival of TIMOs and REITs on the forested landscape, eleven Landsat scenes were used to detect harvest activity within the Alabama counties of Bibb, Hale, Pickens, and Tuscaloosa from 1984 to 2014. Detected harvesting activity was paired with county parcel data and then classified based on landowner type: REITs, TIMOs, forest product industry, government, and non-industrial private forest (NIPF) landowners. Overall harvest trends showed a decrease in harvest rates from 1984 to 2005 with a slight increase in harvest rates after 2005. Per scene interval, acres harvested were highly variable for NIPF and relatively stable for forest industry during this time. Government ownership maintained relatively low and stable harvesting behavior throughout the study period. Acres harvested by REITs was relatively low. TIMOs showed an ever increasing rate of harvest within the study area until the last scene interval (2011-2014).
\end{abstract}

Keywords: GIS, REITs, remote sensing, TIMOs

\section{Introduction}

In the last 25 years, numerous vertically integrated forest products companies, corporations who owned everything from the mills to the forestland, have divested of their forestland ownership. This change of forestland ownership has given rise to a diverse new group of landowners: real estate investment trusts (REITs) and timberland investment management organizations (TIMOs). This change in ownership has presented a plethora of concerns regarding land-use change, fragmentation, and conservation due to the nature of these entities' objectives (Turner et al., 1996; Crow et al., 1999; Block \& Sample, 2001; Clutter et al., 2005). Although the long-term outcomes of these concerns are unclear, REITs and TIMOs have been associated with common land use patterns of intensive timber management and higher and better use (HBU) conversion (Bliss et al., 2010).

TIMOs generally operate on relatively short land management timelines, typically 10 to 15 years. During this time, many forest stands are intensively managed in a plantation setting which include management activities such as site preparation, artificial planting, mechanical, and chemical treatments (Arano \& Munn, 2006). Afterwards, the property is often sold to another investment organization or sold to be converted for HBU such as housing or commercial development (Stein, 2011). This short timeline raises the concern that more frequent ownership changes will lead to increased forest fragmentation and parcelization rates (Wear et al., 2007).

REITs, which do not operate on such short timelines, are similar to TIMOs in that both entities share the goal of maximizing financial returns for investors. As a result, it has been suggested both REITs and TIMOs may be more willing to convert forestland to other non-forest uses to help maximize returns when forest management alone will not (Hickman, 2007).

The amount of timberland owned by REITs and TIMOs has been rapidly increasing in the United States. During 
the early 1980s, the forest products industry owned around 69 million acres of the United States' forestlands and 39 million acres in the Southeast (AL, AR, FL, GA, KY, LA, MS, NC, OK, SC, TN, TX, VA) (Smith et al. 2004). During this time the top fifteen largest forestland owners were all vertically integrated forest product companies. By 2010, only one of those top fifteen remained with ten of the fifteen becoming TIMOs and four becoming REITs (Stein, 2011). From 2004 to 2007, industry owned timberland declined by 17.4 million acres while REITs gained 3.4 million acres and TIMOs gained 12.2 million acres in the United States (Harris, 2007). As of today, REITs and TIMOs manage more than 23 million acres of forestland in the United States (Evans \& Myers, 2015).

The southeastern United States has seen the largest conversion of forest industry timberlands to REITs and TIMOs ownership. This is because, in part, to the region's large and productive forested landbase (Allen et al., 2005; Clutter et al., 2005). From 1996 to 2004, a total of 18.4 million timberland acres were sold in the Southeast (Clutter et al., 2005). Louisiana was most impacted at 3.6 million acres in timberland sales with Alabama (2.6 million acres) and Georgia (2.3 million acres) as the next highest. As of 2010, it was estimated that REITs owned 7.7 million acres and TIMOs owned estimated 8.8 million acres in the Southeast (Zhang et. al., 2012).

This shift in ownership has the potential to impact many southern states economically as well as ecologically, in view of the fact that many have relied of forests and forestland for livelihood for over a century. For example, 70 percent of the state of Alabama is in forestland. It ranks 5th in species diversity in the United States and is the most ecologically diverse state east of the Mississippi River (Stein, 2002). Sales of forest products and related sectors in Alabama total \$11.2 billion as of 2010 (Fields et al., 2013). Yet, it ranked second in the amount of timberland sold between 1996 to 2004 (2.6 million acres). During this same time, Clutter et al. (2005) noted large changes in landownership in west-central Alabama from 1996 to 2004. Additionally, companies such as International Paper (IP), a formerly vertically-integrated forest products company which was a major landowner in Tuscaloosa County and surrounding areas, sold all of their land around 2006.

One of the ways to investigate these forested landscape changes is through satellite imagery. Landsat satellite imagery has long been used for monitoring the forested landscape and is a relatively accurate and effective way to document landscape changes for the use of ecological applications (Cohen and Goward, 2004). Likewise, vegetation indexes, such as the Normalized Difference Vegetation Index (NVDI) and Vegetation Change Tracker (VCT) algorithms have been successfully applied to research regarding temporal and spatial trends and variation in vegetation distribution, productivity and dynamics, monitoring of habitat degradation and fragmentation, and the ecological effects such as drought or fire (Huang et al., 2009; Pettorelli et al., 2005). Additionally, the use of parcel and property tax assessor's data can allow for harvest activity to be identified by landowner type (Jin \& Sader 2006, Randle et al., 2015).

More studies are needed to address the effects that the rise of REITs and TIMOs and decline of forest industry forestland ownership have had on the forested landscape (Clutter et al., 2005; Hickman, 2007; Noone et al., 2012). Therefore, linking harvesting activity with forestland ownership could provide insight to changes to forestland ownership as well as behavioral patterns when forestland is sold over a period of time (Jin \& Sader 2006). The objectives of this research were to: (i) identify the extent of forest industry's divestment of forestland in west-central Alabama during the period from 1984 to 2014 and (ii) assess harvest activity by landowner type during that time.

\section{Methods}

\subsection{Study Area}

For this current study we chose to examine landownership change in the west-central Alabama counties of Bibb, Hale, Pickens, and Tuscaloosa. These counties represent diverse landownership, population demographics, and encompass multiple geographic regions and forest types. Also this area has a rich forest history as it was the historical home to the Kaul Lumber Company, a large vertically integrated lumber company of the early 1900s. This area is now home to the Westervelt Company, a large locally-owned vertically integrated company, in addition to other forest products companies. This area is home to the city of Tuscaloosa which is the fifth largest city in the State. Furthermore, programs such as the Forest Legacy Program have placed high conservation priorities on Bibb (Priority 1), Hale (Priority 2), and Tuscaloosa County (Priority 2) (Boyce et al., 2002). These priorities, which rank areas within the State for conservation need, were set to help protect ecosystems such as dolomite glades, Fall Line Hills longleaf pine forests, and riparian corridors and associated forested wetlands along rivers such as the Sipsey and Cahaba Rivers to the growing human pressure on these biodiversity "hotspots". Pickens County is also of interest as it is one of the highest timber producing counties in Alabama and is 83 percent forested (Alabama Forestry Commission 2011). 


\subsection{Sampling Procedures}

Landsat 5 (launched in 1984 and decommissioned in 2013) and Landsat 8 (launched in 2013 and still active) are low Earth orbit satellites that collect imagery at a 15-30-meter resolution. Leaf-on Landsat 5 and 8 imagery taken between the months of March and October with 0 to 20 percent cloud cover was downloaded from Glovis (http://glovis.usgs.gov/) for the following years: 1984, 1987, 1990, 1993, 1996, 1999, 2002, 2005, 2008, 2011, and 2014 for Path/Row 21/37 and 20/37. As designated by the Worldwide Reference System (WRS) global notation system for Landsat data, Path/Row 21/37 and 20/37 encompasses the entirety of the study area. Harvest change detection accuracy increases as imagery dates are closer together, therefore 2 to 3 years between images can allow for suitable detection accuracy for clearcuts as well as forest harvest activity that does not completely remove the overstory canopy (Wilson \& Sader 2002).

Satellite images for each year were converted to Top of Atmosphere (TOA) reflectance for the purposes of improving the use of vegetation indexes (Chander \& Markham 2003; USGS, 2015). For the purpose of vegetation detection, a NDVI, transformed NDVI, Soil-adjusted Vegetation Index (SAVI), and a transformed SAVI were tested with the transformed NDVI giving the best results (Rouse et al., 1973; Huete, 1988). To avoid agriculture change detection, a forest/non-forest mask was created from the 1996, 2001, 2006, and 2011 National Landcover Dataset and was used to mask non-forested areas by selecting and merging pixels identified as "Deciduous", "Evergreen", "Mixed", or "Woody Wetlands" (Vogelmann et al., 2001; Homer et al., 2007; Fry et al., 2011; Homer et al., 2015). If needed, a cloud mask was also applied to each scene to avoid false positives as a result of clouds or cloud shadow.

Changes in forest cover were calculated by subtracting the transformed NDVI values of a Landsat image from that of the preceding image with an imagery differencing technique

$$
D x \frac{k}{i j}=x \frac{k}{i j}\left(t_{2}\right)-x \frac{k}{i j}\left(t_{1}\right)+C
$$

where $x \frac{k}{i j}=$ pixel value for band $k$ and $i$ and $j$ are line and pixel numbers in the image, $t_{1}=$ first date, $t_{2}=$ second date, and $C=$ a constant to produce positive digital numbers (Singh, 1989). Harvest activity was then statistically derived from the average NDVI value by adjusting the threshold by one standard deviation for each scene and then empirically adjusting the thresholds to best fit the scene based on harvesting records from the study area. Each scene was then subsequently reclassified into change and non-change thematic maps. The thematic layer was then converted to polygons and all areas greater than 10 acres were extracted and the resulting image was clipped to the study area. On-screen visual interpretation was then employed to correct errant omissions, remove false positives, and to improve overall accuracy with the aid of Landsat imagery, Google Earth, NDVI change detection rasters, and NAPP Imagery (Borrelli et al. 2014). An accuracy assessment via was conducted using harvesting records of known locations and then verified by on-screen visual interpretation. A confusion matrix on a per-pixel basis $(n=500)$ produced an overall classification accuracy of 96.2 percent and a Kappa Index of Agreement of 0.924 (Congalton, 1991).

For the purpose of detecting harvesting behavior by landowner type, harvest polygons were identified with landowner attribute data as developed for each county. Based on the methods of Randle et al. (2015), a landowner database was created from property books for each county from the late 1980s and the early 1990s and compared to county tax assessors GIS databases from 2014. Harvest polygons were then categorized into the following landowner types: REITs, TIMOs, forest product industry, government, and non-industrial private forest (NIPF) landowners. Figure 1 provides the methods for the entire process (adapted from Borrelli et al., 2014). 


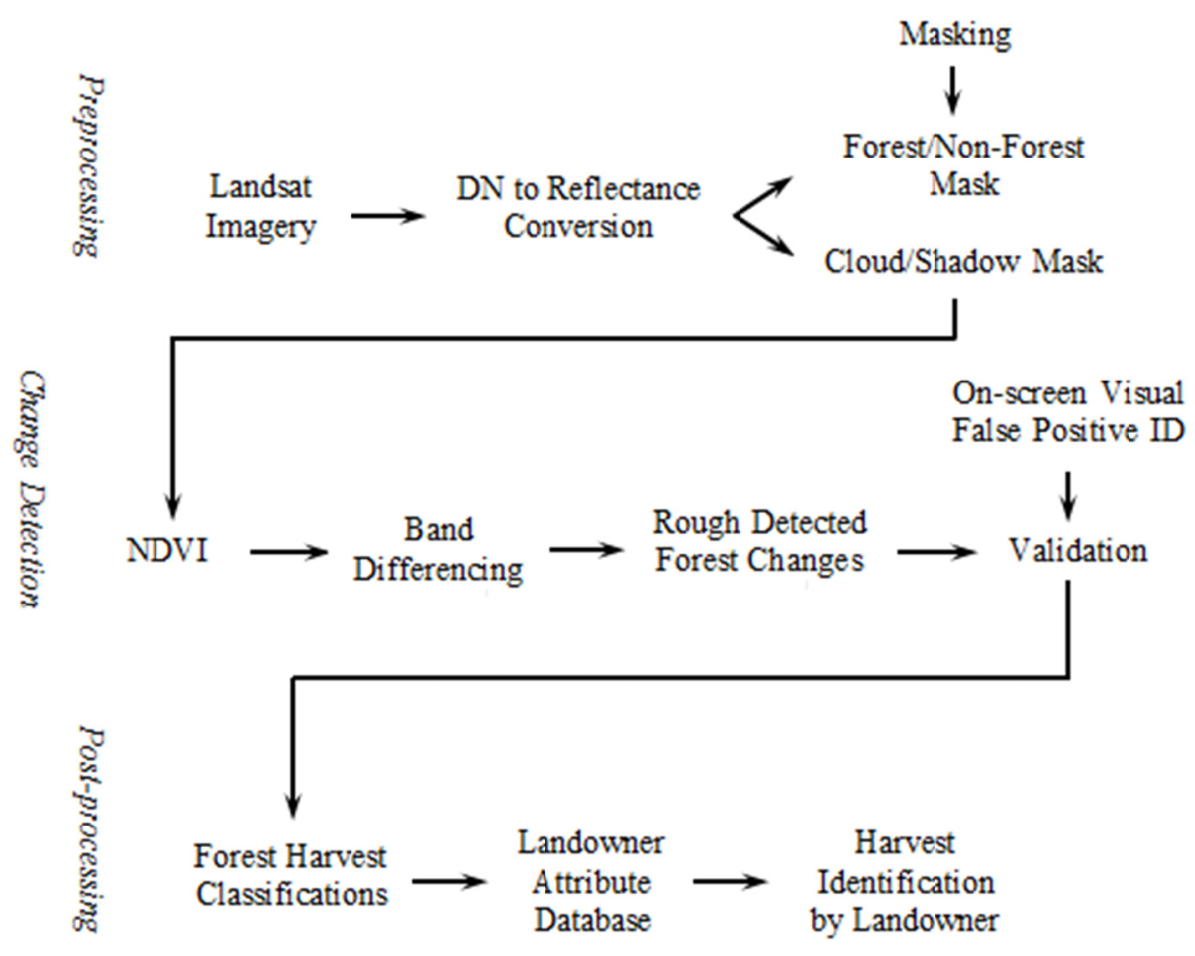

Figure 1. Methods for the detection of forest cover change and landowner identification for properties in Bibb, Hale, Pickens, and Tuscaloosa Counties

For the purpose of understanding TIMO harvest behavior after a parcel was purchased, TIMO parcels that had harvest activity on them were classified by scene intervals ( 3 years) from the last purchase of the deed (Table 1). For example, both a parcel that was purchased in 2006 and cut in 2007 and a parcel purchased in 2012 and harvested in 2013 would both be classified as 0, indicating that the parcel was harvested in the same harvest detection interval as it was purchased (Table 1). A parcel that was harvested 1 scene before the deed was purchased would be classified as a -1; A parcel that was harvested 1 scene after the deed was purchased would be classified as a 1 .

Table 1. TIMO deed purchase and harvest detection interval classifications.

$-4 \leq$ Parcel was harvested 4 or more harvest detection intervals before the deed was purchased

-3 Parcel was harvested 3 harvest detection intervals before the deed was purchased

-2 Parcel was harvested 2 harvest detection intervals before the deed was purchased

-1 Parcel was harvested 1 harvest detection interval before the deed was purchased

0 Parcel was harvested in the same harvest detection interval as it was purchased

1 Parcel was harvested 1 harvest detection interval after the deed was purchased

2 Parcel was harvested 2 harvest detection intervals after the deed was purchased

3 Parcel was harvested 3 harvest detection intervals after the deed was purchased

$4 \geq \quad$ Parcel was harvested 4 or more harvest detection intervals after the deed was purchased 


\section{Results}

\subsection{Landownership Changes}

A total of 405,048 acres were identified as being owned by the forest products industry from the late 1980s and early 1990s which comprised 22 percent of the 1,841,000 acres of forestland in the four counties in this current study (Table 2, Figure 2, and Figure 3). Thirty-one different forest product companies ranging from large corporations to local family mills were found in the study area during this time. As of 2014, the forest products industry retained 44.5 percent of their former ownership in the area. REITs and TIMOs, as of 2014, owned 140,775 acres or 34.8 percent of the previous forest products industry forestland representing over half of the acres in new ownership. NIPF landowners acquired 75,402 acres or 18.6 percent of former forest industry forestland while varying government entities acquired around 8,537 acres or 2.1 percent, respectively. In terms of total ownership, former forest industry timberland only represented 61 percent of the total TIMO ownership within the four counties (Table 2). For REITs and forest products industry, former forestry products industry land represented 75 percent and 89 percent, respectably, of their entire landbase. Five and half percent of NIPF landowners Despite the forest products industry, as a whole, selling large amounts of their land from the 1990s to 2014, a few forest product companies acquired roughly 23,000 acres that were not former forest industry land.

Table 2. Ownership in 2014 by acres from forestry industry forestland and percent total forestland ownership by acres for Bibb, Hale, Pickens, and Tuscaloosa Counties, Alabama

\begin{tabular}{lrrrr}
\hline & $\begin{array}{r}\text { 2014 Ownership of } \\
\text { Land Acquired from } \\
\text { Forest Industry } \\
\text { (Acres) }\end{array}$ & $\begin{array}{r}\text { 2014 Percent } \\
\text { Ownership of } \\
\text { Land Acquired } \\
\text { from Forest } \\
\text { Industry }\end{array}$ & $\begin{array}{r}\text { 2014 Total } \\
\text { Ownership by } \\
\text { Landowner } \\
\text { (Acres) }\end{array}$ & $\begin{array}{r}\text { 2014 Percent of Former } \\
\text { Forest Industry Land } \\
\text { Acquired to Total } \\
\text { Ownership }\end{array}$ \\
\hline NIPF $^{1}$ & 75,402 & 18.6 & $1,378,117$ & 5.47 \\
Government $_{\text {Industry }}$ & 8,537 & 2.1 & 37,802 & 22.6 \\
REIT $^{2}$ & 180,333 & 44.5 & 203,260 & 88.7 \\
TIMO $^{3}$ & 27,100 & 6.7 & 35,969 & 75.3 \\
\hline Total & 113,675 & 28.1 & 185,852 & 61.2 \\
\hline 1. Nonindustrial Private Forest Landowners & 100 & $1,841,000$ & \\
2. Real Estate Investment Trusts & & \\
3. Timber Investment Management Organizations & &
\end{tabular}




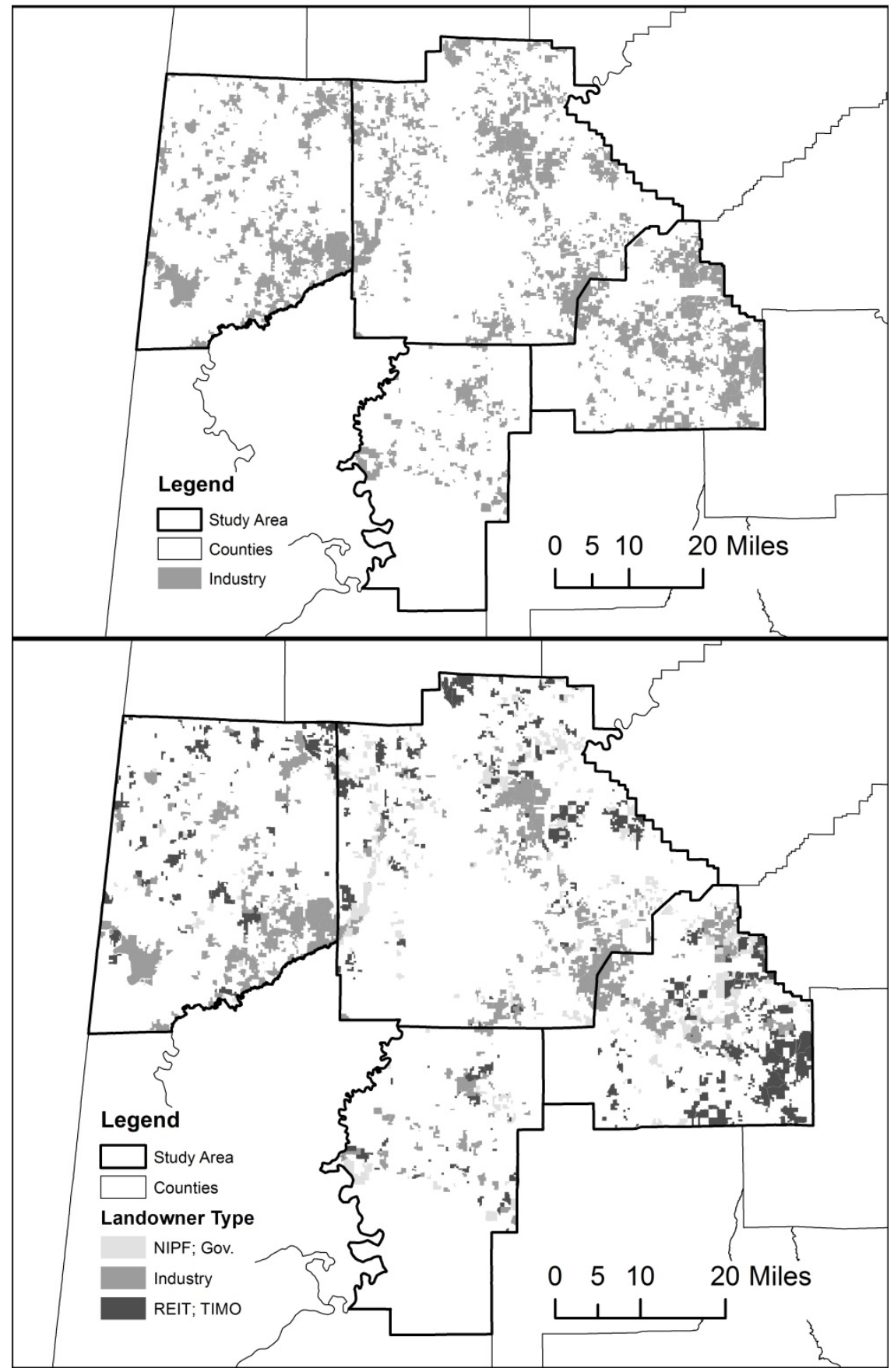

Figure 2. (Top) Forest product industry forestland ownership from the late 1980s and early 1990s for Bibb, Hale, Pickens, and Tuscaloosa Counties, Alabama. (Bottom) Forestland ownership by landowner type as of 2014 acquired from forest products industry for Bibb, Hale, Pickens, and Tuscaloosa Counties, Alabama 


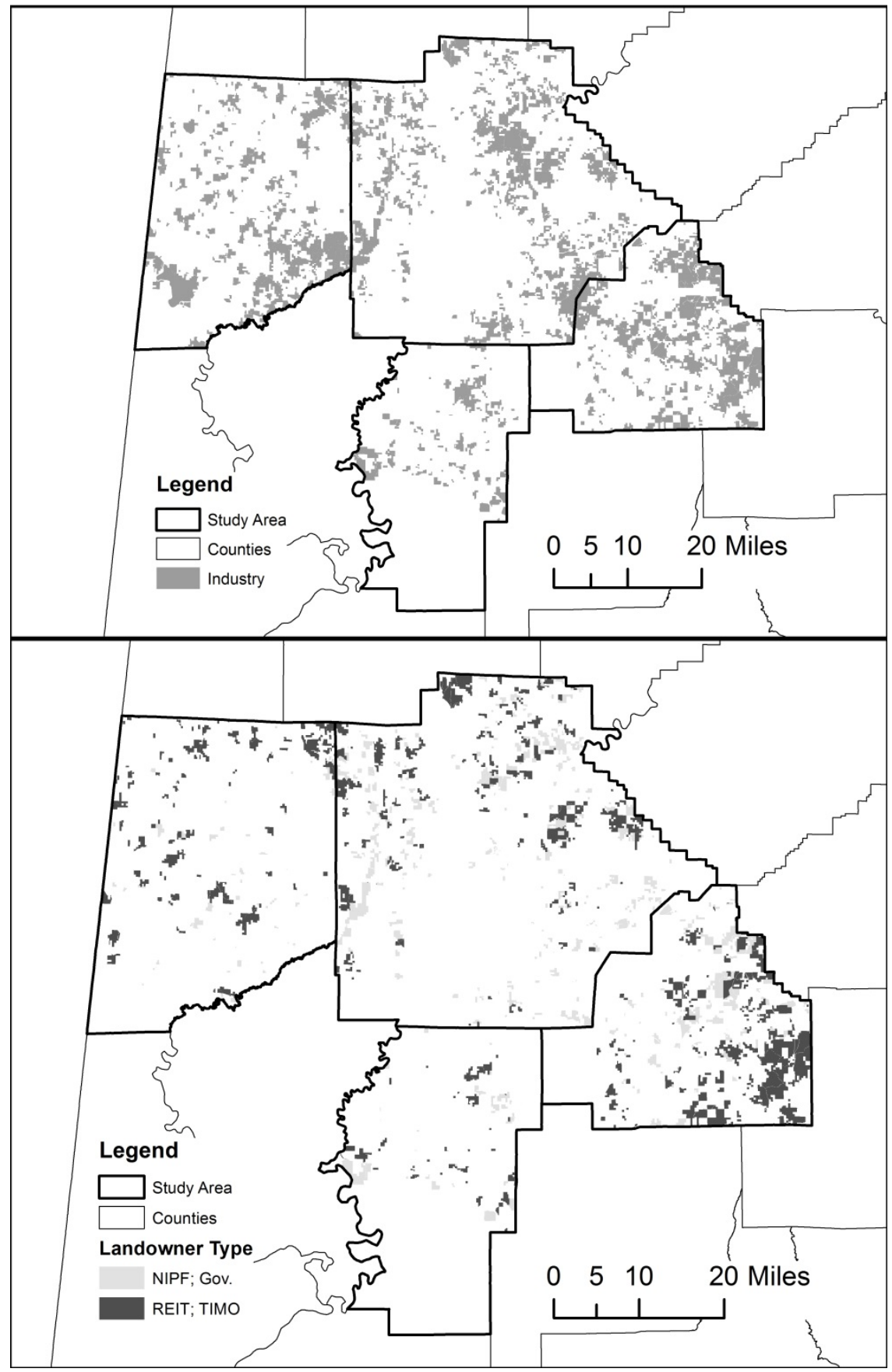

Figure 3. (Top) Forest product industry forestland ownership from the late 1980s and early 1990s for Bibb, Hale, Pickens, and Tuscaloosa Counties, Alabama. (Bottom) Change in landowner type of non-forest products industry as of 2014 from forest products industry for Bibb, Hale, Pickens, and Tuscaloosa Counties, Alabama

\subsection{Parcelization}

From the late 1980s and early 1990s to 2014, the number parcels owned by forest industry increased at various rates (Table 3). Tuscaloosa and Bibb Counties showed high rates of parcelization as the result of land sales while Pickens and Hale Counties showed a much lower rate. Increases in parcels were positively correlated to increases of county population but were not statistically significant (Pearson's $\mathrm{R}=0.927, \mathrm{P}>0.05$ ). Total change in parcels were positively correlated with total changes in population within an individual county (Pearson's $\mathrm{R}=$ $0.959, \mathrm{P}=0.04)$. 
Table 3. Number of parcels and parcel change for forest products industry owned land from the late 1980s and early 1990s for Bibb, Hale, Pickens, and Tuscaloosa Counties, Alabama

\begin{tabular}{lrrrrr}
\hline & $\begin{array}{r}\text { Number of Parcels } \\
\text { in the Late 1980s } \\
\text { and Early 1990s }\end{array}$ & $\begin{array}{r}\text { Number of } \\
\text { Parcels in 2014 }\end{array}$ & $\begin{array}{r}\text { Percent } \\
\text { Increase }\end{array}$ & $\begin{array}{r}\text { Total Change } \\
\text { in Parcels by } \\
\text { County }\end{array}$ & $\begin{array}{r}\text { Total Change in } \\
\text { Population by } \\
\text { County }\end{array}$ \\
\hline Bibb & 514 & 857 & 66.7 & 343 & 6,021 \\
Hale & 227 & 253 & 11.5 & 26 & 262 \\
Pickens & 695 & 762 & 9.6 & 67 & -953 \\
Tuscaloosa & 925 & 1,699 & 83.7 & 774 & 44,134 \\
\hline
\end{tabular}

\subsection{Harvesting}

From 1984 to 2014, a total of 1,159,970 acres or 63 percent of all forestland between the four counties as of 2014 were detected as harvested within the study area (Figure 4). This is supported by a report from the USDA Forest Service (1988) who showed that increasing timber removal trends and silvicultural practices at the time during the 1950s through the 1970s would continue into the following decades. Large areas of no harvest activity in Tuscaloosa were because, in part, of land area taken up by the City of Tuscaloosa, the fifth highest populated city in Alabama which covers a total of 44,998 acres. Lack of harvesting in the southwest portion of Pickens County and the southern portion of Hale County correspond with the Black Belt region, a region traditionally associated with crop production agriculture.

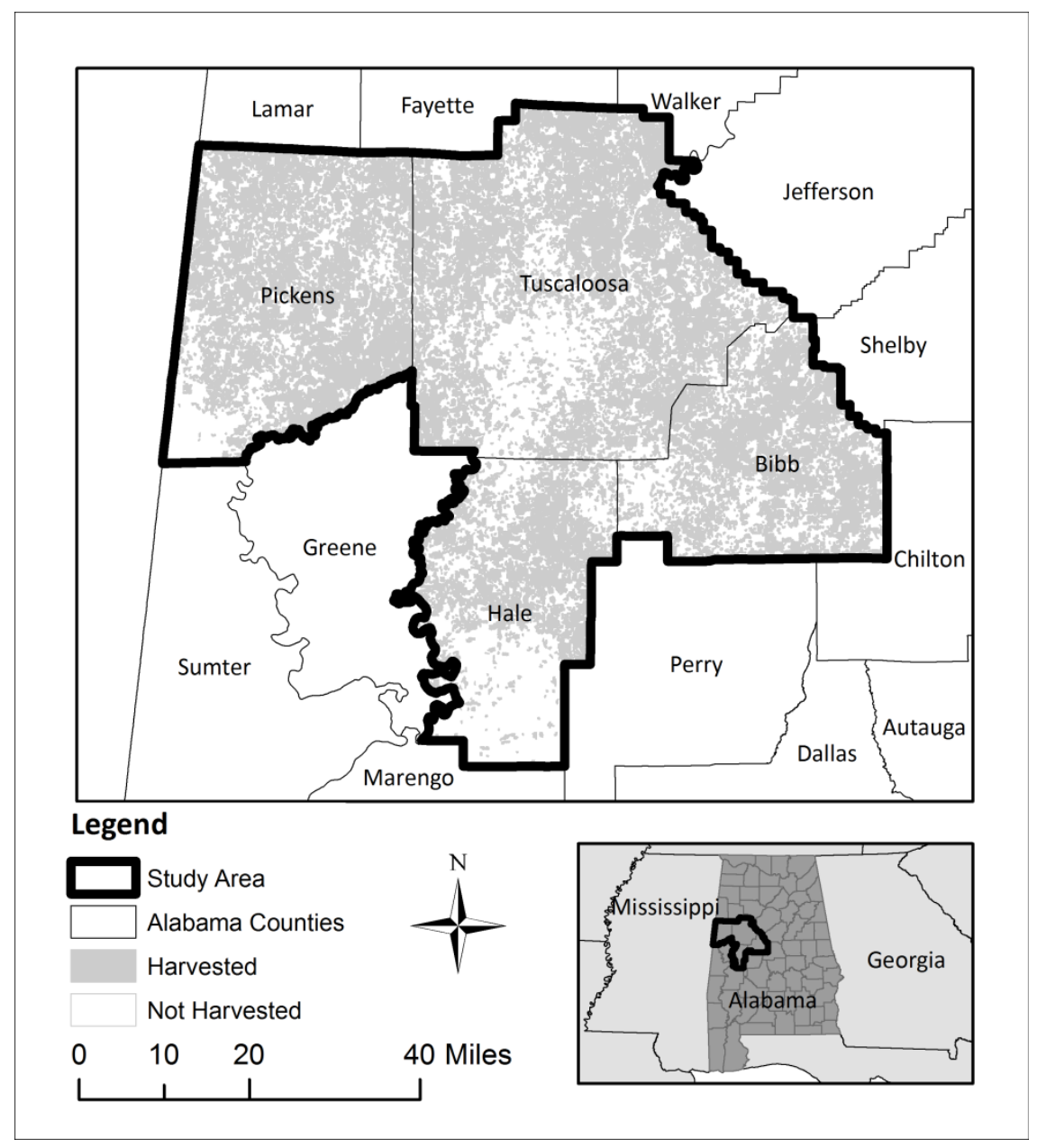

Figure 4. Location of acres harvested between 1984 through 2014 for Bibb, Hale, Pickens, and Tuscaloosa Counties, Alabama 
Harvest acreage by landowner type showed slightly different trends through time (Table 4 and Figure 5). NIPF landowner's harvesting behavior was cyclic, however, they maintained the highest amount of harvested acres through in all detection intervals from 1984 to 2014 and would consistently account for half or more of the harvested acres per harvest detection interval. For NIPF landowners, harvested acreage rose sharply during 1993 and then declined until 2002. Harvested acreage for NIPF landowners increased from 2002 until 2008 when acres harvested again declined until 2011.

Forest products industry shows relatively stable harvesting behavior throughout the time period with the exception of 2011 to 2014, which showed a decline. Forest products industry consistently accounted for 25 percent to 35 percent of total harvested acres per harvest detection interval. TIMO harvested acres increased from 1996 to 2011 and then declined after 2011. Harvested acres by TIMOs would not exceed forest industry harvest acres at any given harvest detection interval. REIT harvested acreage was absent until the 2011 to 2014 harvest detection interval. Government agencies such as the US Forest Service and US Fish and Wildlife Service maintained a low and relatively stable rate of harvesting throughout the study period.

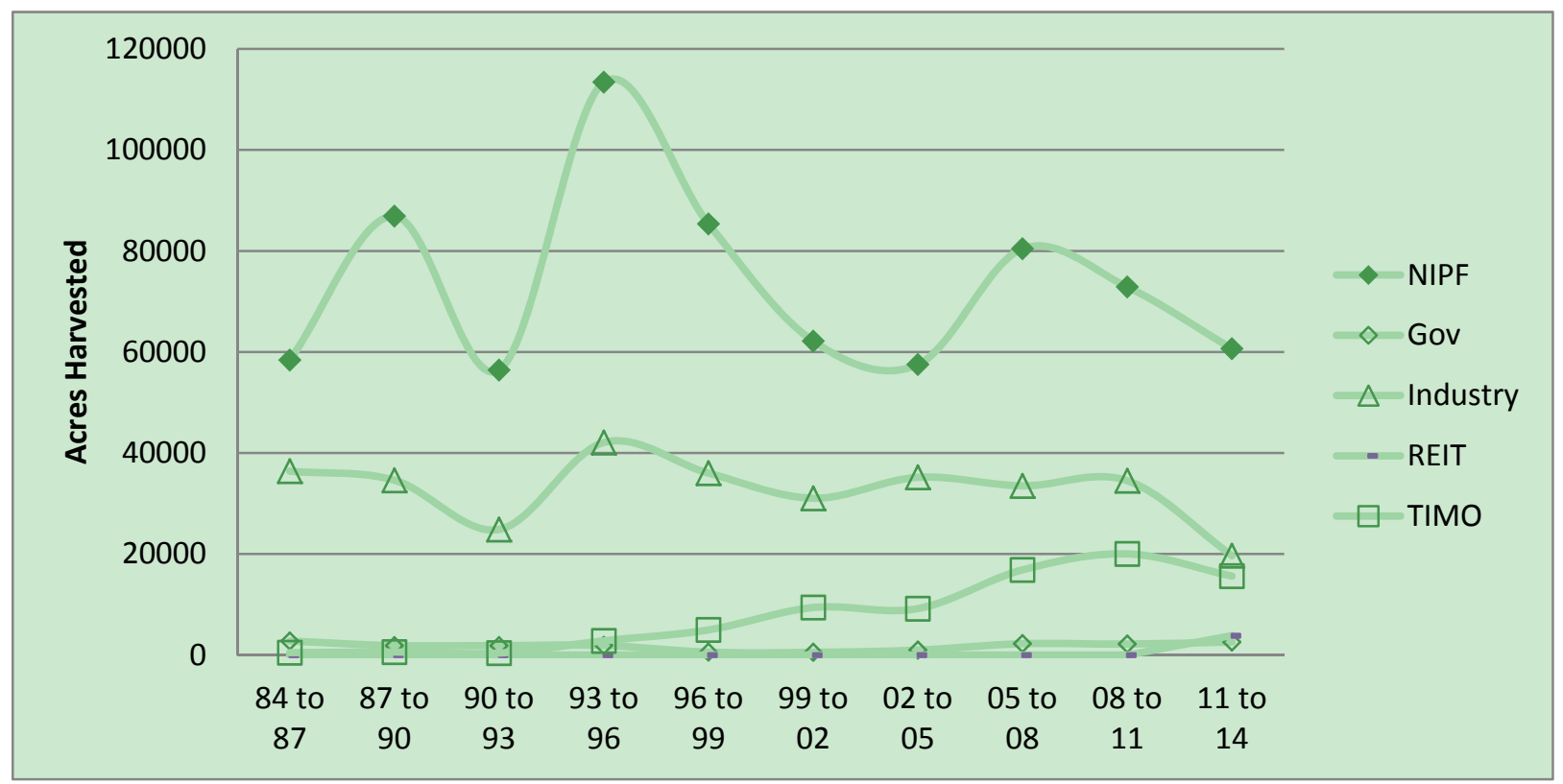

Figure 5. Acres harvested between 1984 to 2014 by landowner type in Bibb, Hale, Pickens, and Tuscaloosa Counties, Alabama 
Table 4. (Top) Acres harvested between 1984 to 2014 by landowner type in Bibb, Hale, Pickens, and Tuscaloosa Counties, Alabama by scene interval years. (Bottom) Percentages of acres harvested within a scene interval between 1984 to 2014 by landowner type in Bibb, Hale, Pickens, and Tuscaloosa Counties, Alabama

\begin{tabular}{lrrrrrrrrrr}
\hline Type & $84-87$ & $87-90$ & $90-93$ & $93-96$ & $96-99$ & $99-02$ & $02-05$ & $05-08$ & $08-11$ & $11-14$ \\
\hline NIPF $^{1}$ & 58,377 & 86,895 & 56,409 & 113,430 & 85,350 & 62,148 & 57,518 & 80,454 & 72,874 & 60,644 \\
Government & 2,764 & 1,866 & 1,880 & 1,884 & 582 & 549 & 982 & 2,251 & 2,174 & 2,587 \\
Industry & 36,400 & 34,606 & 24,870 & 42,075 & 36,019 & 31,047 & 35,181 & 33,496 & 34,518 & 19,672 \\
REIT $^{2}$ & 0 & 0 & 0 & 0 & 0 & 0 & 0 & 0 & 0 & 3,860 \\
TIMO $^{3}$ & 481 & 600 & 402 & 2,816 & 4,977 & 9,418 & 9,197 & 16,872 & 20,028 & 15,627 \\
\hline Total $^{2}$ & 98,022 & 123,967 & 83,561 & 160,205 & 126,928 & 103,162 & 102,878 & 133,073 & 129594 & 102,390 \\
\hline NIPF $^{1}$ & 59.6 & 70.1 & 67.5 & 70.8 & 67.2 & 60.2 & 55.9 & 60.5 & 56.2 & 59.2 \\
Government $^{2.8}$ & 1.5 & 2.2 & 1.2 & 0.5 & 0.5 & 1.0 & 1.7 & 1.7 & 2.5 \\
Industry $^{2.8}$ & 37.1 & 27.9 & 29.8 & 26.3 & 28.4 & 30.1 & 34.2 & 25.2 & 26.6 & 19.2 \\
REIT $^{2}$ & 0.0 & 0.0 & 0.0 & 0.0 & 0.0 & 0.0 & 0.0 & 0.0 & 0.0 & 3.8 \\
TIMO $^{3}$ & 0.5 & 0.5 & 0.5 & 1.8 & 3.9 & 9.1 & 8.9 & 12.7 & 15.5 & 15.3 \\
\hline Total $^{2}$ & 100 & 100 & 100 & 100 & 100 & 100 & 100 & 100 & 100 & 100
\end{tabular}

1. Nonindustrial Private Forest Landowners

2. Real Estate Investment Trusts

3. Timber Investment Management Organizations

\subsection{TIMO Harvest Behavior}

Figure 6 shows that parcels purchased by TIMOs, classification 0 (parcel was harvested in the same harvest detection interval as it was purchased) had the highest frequency with 1 and 2 classifications having the next highest frequencies respectively. On average, a parcel was harvested 1.17 (+/- 1.55, CI 95) scene intervals from when its deed was acquired $(\mathrm{P}<0.005)$. Based on our findings, a parcel has a 50 percent chance that in $1.17(+/-$ 0.11 , CI 95) scene intervals ( 1 to 5 years) that it will be harvested from the deed is purchased and a 90 percent chance that it will be harvested within 3.16 (+/- 0.24, CI 95) scene intervals (1 to 10 years). 

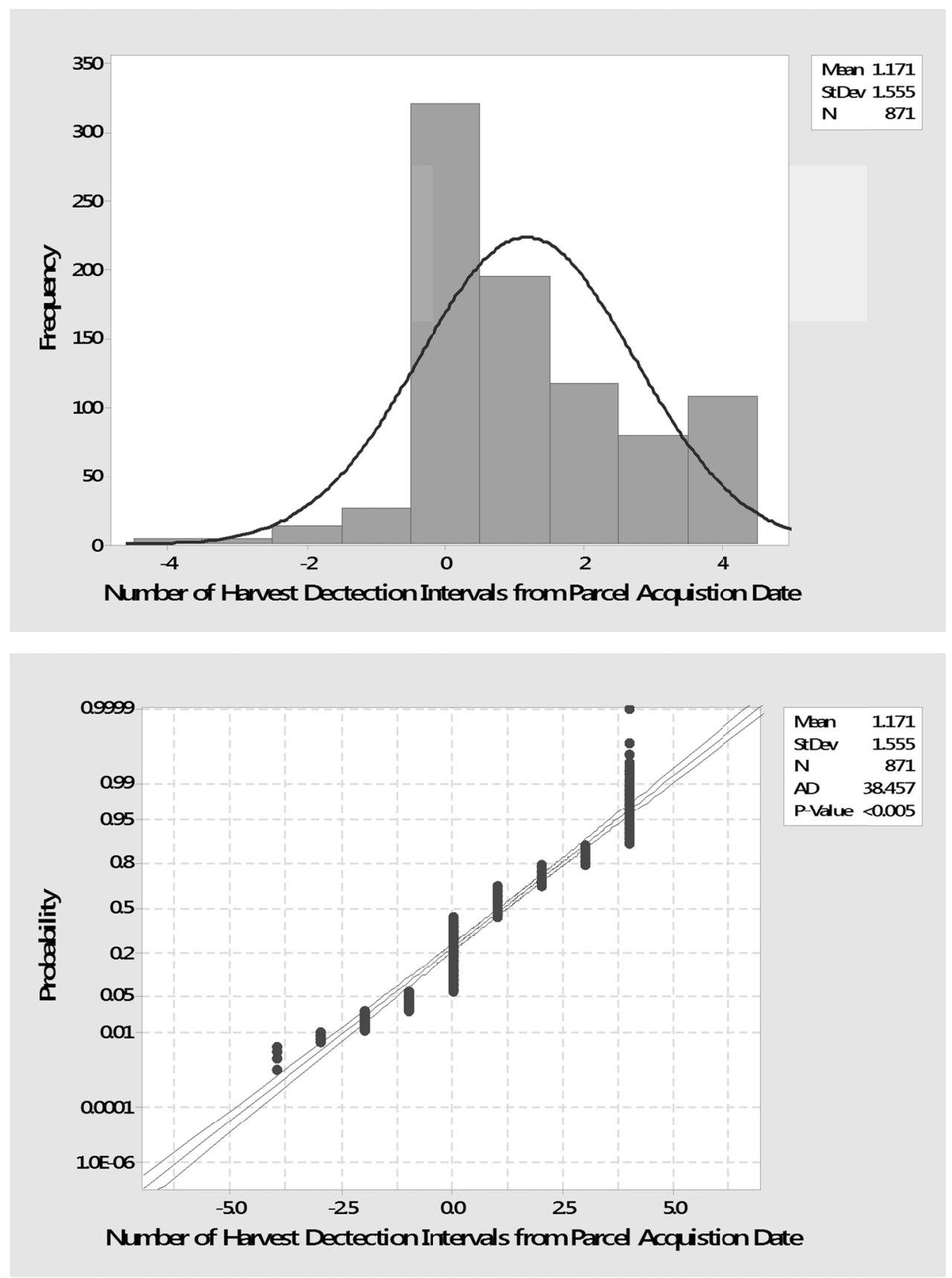

Figure 6. (Top) Distribution of scenes that occurred within a given scene interval based on the deed purchase date. (Bottom) Probability (with 95\% CI) of harvest activity occurring at each scene from the deed purchase date from 1984 to 2014 for TIMOs in Bibb, Hale, Pickens, and Tuscaloosa Counties, Alabama

\section{Discussion}

\subsection{Landownership Changes}

Despite the forest products industry losing roughly half of their former acreage in the study area, corporations showed variable behaviors. The Westervelt Company, headquartered in Tuscaloosa, Alabama, took advantage of various entities selling their forestland and bought more land than it sold. Other corporations with local roots such as McShan Lumber Company and Melrose Timber Company, also held on to the majority of their land. Both of the companies also started during the 1800 s and their landbases were comprised of local area landholdings.

Other companies such as IP and Weyerhaeuser showed much different behavior largely due to financialization 
and pressure for increased shareholder returns (Gunnoe, 2016). For IP, the company made acquisitions during the 1980s through the 2000s such as the Hammermill Paper Company in 1986, Federal Paper Board in 1996, Union Camp Corporation in 1999, and Champion International Paper in 2000. In 2005-2006, IP restructured by selling over six million acres and several mills to various companies. Within the study area, IP would sell roughly 40,700 acres.

IP restructuring resulted from the weak performance of the forest products industry in the 1990s, which included poor shareholder returns (Gunnoe, 2016). Additionally, some forest products companies had accrued large amounts of debt to enhance their international competiveness by way of consolidations (Block \& Sample, 2001). Rising land price coupled with changing mentality that forestland ownership was no longer necessary to ensure the future availability of raw materials at a reasonable cost led to the forest industry selling their landbase (Hickman, 2007). The selling of forestlands this way, in part, helped to reduce debt, to help break the trends of weak financial performance, and help to improve returns (Clutter et al., 2005). Similar to IP, Weyerhaeuser had acquisitioned other timber companies such as MacMillan Bloedel in 1999. Pressured by similar reasons as IP, Weyerhaeuser took a different path by transitioning from a C-corporation to a REIT status in 2010.

The onset of TIMOs was due to several variations in landowner behavior but the most prevalent trend was as timber companies divested parts or the entirety of their landbase, TIMOs took advantage of mass land holdings being sold. Forest product companies such as the Olon Belcher Lumber Company, Kimberly Clark, and Albert Holman Lumber Company sold parts or all of their landbase in the late 1990s and early 2000s allowing various TIMOs to establish themselves. This trend would continue with IP who sold off its entire landbase to TIMOs such as the Red Mountain Timber Company in 2006 through 2008. Other forest industry companies such as Westervelt, Weyerhaeuser, and Melrose Timber Company have continued to sell off parts taking advantage of HBU. Other small mill owners sold their forestland during this time taking advantage of high land prices during the early 2000s. Others suffered as forest product demand greatly plummeted after the house market crash in 2008. Another trend was that some large local family landowners took advantage of HBU and sold some of their land holdings to TIMOs. Lastly, some investment companies would acquire already established forested landbases owned by other investment companies. One example is the acquisition of the Canterbury Trust, an investment and consulting services company, by Synovous Financial Corp, a multi-financial services company, in 1999.

Trends seen in this study were seen by Randle (2015) in five counties in Southwest Alabama who found that 63 percent of all industry lands were sold to corporate owners; entities that are not connected to wood product mills. Randle, (2015) also found, Cedar Creek and T.R. Miller, 2 large timber products companies, maintained ownership of their lands similar to Westervelt in the Tuscaloosa area. In Northwest Maine, $80 \%$ of forest industry land was sold, with 75 percent being sold to TIMOs and the other 25 percent being sold to other industrial land owners (Jin \& Sader, 2006).

\subsection{Parcelization}

In Pickens and Hale County there was little parcel change as a result of companies like Westervelt selling little land resulting in minute parcel change. IP had large landholdings located in Bibb which were sold and resulted in splitting parcels for HBU. For Tuscaloosa, large changes were the result of HBU conversion as companies like Weyerhaeuser and Westervelt developed and/or sold forestland for residential parcels along the Black Warrior River, Sipsey River, and around the city of Tuscaloosa. This is supported by Hartsell and Vissage (2001) who reported for west-central Alabama that roughly 80 percent of land diverted from timberland has been cleared for urban and related land use, particularly around the Tuscaloosa area.

\subsection{Harvesting}

The relatively stable harvesting rates of forest industry until 2008 might be explained for several reasons (Figure 4). Westervelt, one of the largest landowners in the study area, would maintain the majority of its landbase. The dip in 2008-2011 also corresponds with the transition of Weyerhaeuser to a REIT in 2010 and closure of several smaller mills after the financial crisis of 2008. To date, Weyerhaeuser's conversion to a REIT has not shown any difference in harvested acres between pre-REIT and post-REIT status.

Harvesting patterns associated with NIPF landowners and to a lesser degree forest products industry follow the cyclical nature of the general economy and this is reflected in the number of harvested acres (Figure 4) (Newman \& Wear, 1993). Industry satisfied the supply of timber needs from their own land while procuring additional timber via the open market from NIPF and other landowner types. In 1993, stumpage prices for northern Alabama doubled compared to the 1992 prices as seen in the large spike of harvest acres in Figure 4. Similarly, increases in 2002 to 2008 mirrors the economy growth of the early 2000s and after the housing crisis in 2008 
shows a decline. In general, NIPF landowners are more sensitive to price change than their industrial counterpart and are more willing to delay a harvest until stumpage prices are more favorable to the landowner (Newman \& Wear, 1993). However, NIPF landowner harvesting behavior, which has become increasingly important as a result of forest industry's divestment of land, is still not well understood (Silver et al. 2015).

\subsection{TIMO Harvest Behavior}

The increasing harvest behavior with TIMOs mirrors the increase in acres owned by TIMOs in the study area (Figure 4). Our study found that a parcel or a portion of a parcel had roughly a 50 percent probability of being harvested in the first 5 years after the parcel is acquired. As TIMOs goals are a product of the maximization of Net Present Value (NPV) which are, in part, are influenced by stand age and surrounding markets. One reason for this behavior is that harvesting occurs after land is purchased to re-coup capital that is spent investing into land. Less likely reason is that growing a stand to X age could lower NPV for a stand over a given timeframe. Additionally, land is harvested by the forest landowner before the land is sold. Jin and Sader (2006) found that TIMOs and short-term investors in Maine harvested a higher percentage than forest industry in the 1990s and early 2000s and found that areas that had no change in ownership were much less likely to be harvested.

The impact that this behavior could have on forest diversity in Alabama is unknown. Zhang et al. (2012) showed that TIMOs and REITs in the Southeast are removing twice the amount of hardwood than is annually grown on their lands and suggested a possible reason for these was that a conversion of hardwood forests to softwood forests is occurring in timberlands owned by TIMOs and REITs. Secondly, as TIMOs operate on short timeframes, typically 10 to 15 years, this behavior could have serious ecological implications in the future due to increased fragmentation and parcelization rates (Wear et al., 2007; Bliss et al., 2010). As land holdings are continuously traded, land holdings might be broken in smaller and smaller holdings of land even if the landowner type changes. While parcelization could occur between transfer of land from TIMO to another, this trend of parcelization could have effects on subsequent, non-TIMO landowners as well. The amount of acres owned, how the land was acquired, and length of ownership have been shown to be important indicators for management activity levels (Birch et al. 1982).

\section{Conclusion}

The divestment of land by the forest products industry and the arrival of REITs and TIMOs have different magnitudes on multiple scales (Ameyaw, 2013; Randle et al., 2015; Gunnoe, 2016). These differences are a product of scale as factors such as physiographical regions and differences between local and regional economies (Holling, 2001). These results begin to illuminate the effects of the decline of forest industry's landbase and an ever increasing TIMO landbase on harvesting rates and management behavior. Also, these results presented in this paper help continue to emphasize the current and potential impacts of local economies and societies (Ameyaw, 2013; Randle et al., 2015). Secondly, the methods outlined in this paper offer an effective way to monitor harvest behavior in other regions of the state or other states where it might be of interest. Further monitoring would be beneficial in discovering trends throughout the United States concerning REITs and TIMOs. Additionally, monitoring would help elucidate if there is any divergence from current trends of landownership patterns associated with REIT and TIMO ownership.

\section{References}

Alabama Forestry Commission. (2011). Forest resource report 2011. Montgomery, AL. Retrieved July 12, 2015, from http://www.madeinalabama.com/assets/2013/01/AlabamaForestResourceReport.pdf

Allen, L. H., Fox, T. R., \& Campell, R. G. (2005). What is ahead for intensive pine plantation silviculture in the South. Southern Journal of Applied Forestry, 29(2), 62-69.

Ameyaw, L. K. (2013). Investigating the Objectives of the New Owners of Alabama's Timberlands. [Thesis] Auburn University, Auburn, Alabama.

Arano, K. G., \& Munn, I. A. (2006). Evaluating forest management intensity: a comparison among major forest landowner types. Forest Policy and Economics, 9(3), 237-248. https://doi.org/10.1016/j.forpol.2005.07.011

Birch, T. W., Lewis, D. G., \& Kaiser, H. F. (1982). The private forest-land owners of the United States. Resource Bulletin. WO-I. USDA Forest Service. Radnor, PA. 183 pp. https://doi.org/10.2737/WO-RB-1

Bliss, J. C., Kelly, E. C., \& Abrams, J. (2010). Disintegration of the industrial forest estate and the future of small-scale forestry in the United States. Small-scale Forestry, 9, 53-66. https://doi.org/10.1007/s11842-009-9101-7

Block, N. E., \& Sample, V. A. (2001). Industrial timberland divestitures and investments: opportunities and 
challenges in forestland conservation. Pinchot Institute for Conservation. Washington, DC. $50 \mathrm{pp}$.

Borrelli, P., Modugno, S., Panagos, P., Marchetti, M., Schutt, B., \& Montanarella, L. (2014). Detection of harvested forest areas in Italy using landsat imagery. Applied Geography, 48, 102-111. https://doi.org/10.1016/j.apgeog.2014.01.005

Boyce, T. C., Dumont, D., \& Bailey, M. (2002). Alabama Forest Legacy Program Assessment of Need Document. Alabama Forest Resources Center. Mobile, AL. 79 pp.

Chander, G., \& Markham, B. (2003). Revised Landsat-5 TM radiometric calibration procedures and post calibration dynamic ranges. IEEE Transactions on Geoscience and Remote Sensing, 41(11), 2674-2677. https://doi.org/10.1109/TGRS.2003.818464

Clutter, M., Mendell, B., Newman, D., Wear, D., \& Greis, J. (2005). Strategic factors driving timberland ownership changes in the U.S. South. Retrieved August 28, 2014, from http://www.iatp.org/files/181_2_78129.pdf

Cohen, W. B., \& Goward, S. N. (2004). Landsat's role in ecological applications of remote sensing. BioScience, 54(6), 535-545. https://doi.org/10.1641/0006-3568(2004)054[0535:LRIEAO]2.0.CO;2

Congalton, R. G. (1991). A review of assessing the accuracy of classifications of remotely sensed data. Remote Sensing of Environment, 31(1), 35-46. https://doi.org/10.1016/0034-4257(91)90048-B

Crow, T. R., Host, G. E., \& Mladenoff, D. J. (1999). Ownership and ecosystem as sources of spatial heterogeneity in a forested landscape, Wisconsin, USA. Landscape Ecology, 14, 449-463. https://doi.org/10.1023/A:1008084123874

Evans, T. B., \& Myers, G. A. (2015). Not all TIMOs are alike. Forest Landowner. January/February: 28-33.

Fields, D., Guo, Z., Hodges, A. W., \& Rahmani, M. (2013). Economic impacts of Alabama's agricultural, forestry, and related industries. Retrieved June 19, 2015, from http://www.aces.edu/pubs/docs/A/ANR-1456/ANR-1456.pdf

Fry, J. A., Xian, G., Jin, S., Dewitz, J. A., Homer, C. G., Limin, Y., \& Wickham, J. D. (2011). Completion of the 2006 National Land Cover Database for the Conterminous United States. Photogrammetric Engineering and Remote Sensing, 77(9), 858-864.

Gunnoe, A. (2016). The financialization of the US forest products industry: socio-economic relations, shareholder value, and the restructuring of an industry. Social Forces, 94(3), 1075-1101. https://doi.org/10.1093/sf/sov108

Harris, T. (2007). Industry, TIMOs, REITs, the changing face of forestry: the new private forest landowners. Forest Landowner, 66, 3-5.

Hartsell, A. J., \& Vissage, J. S. (2001). Forest statistics for west-central Alabama, 2000. USDA Forest service Resource Bulletin SRS-60. U.S. Department of Agriculture, Forest Service, Southern Research Station, Asheville, NC. 60 pp.

Hickman, C. (2007). TIMOs and REITs. Retrieved October 1, 2014, from http://thetimberlandblog.blogspot.com/2007/05/timos-and-reits.html

Holling, C. S. (n.d.). Understanding the complexity of economic, ecological, and social systems. Ecosystems, 4(5), 390-405.

Homer, C. G., Dewitz, J. A., Yang, L., Jin, S., Danielson, P., Xian, G., \& Megown, K. (2015). Completion of the 2011 national land cover database for the conterminous United States-representing a decade of land cover change information. Photogrammetric Engineering and Remote Sensing, 81(5), 345-354.

Homer, C., Dewitz, J., Fry, J., Coan, M., Hossain, N., Larson, C., \& Wickham, J. (2007). Completion of the 2001 national land cover database for the conterminous United States. Photogrammetric Engineering and Remote Sensing, 73(4), 337-341.

Huang, C., Goward, S. N., Schleeweis, K., Thomas, N., Masek, J., \& Zhu, Z. (2009). Dynamics of national forests assed using the Landsat record: Case studies in eastern United States. Remote Sensing of Environment, 133, 1430-1442. https://doi.org/10.1016/j.rse.2008.06.016

Huete, A. R. (1988). A soil-adjusted vegetation index (SAVI). Remote Sensing of Environment, 253, 295-309. https://doi.org/10.1016/0034-4257(88)90106-X

Jin S., \& Sader, S. A. (2006). Effects of forest ownership and change on forest harvest rates, types and trends in 
northern Maine. Forest Ecology and Management, 228, 177-186. https://doi.org/10.1016/j.foreco.2006.03.009

Newman, D. H., \& Wear, D. N. (1993). Production economics of private forestry: a comparison of industrial and nonindustrial forest owners. Economics of Private Forestry, 75, 674-684. https://doi.org/10.2307/1243574

Noone, M. D., Sader, S. A., \& Legaard, K. R. (2012). Are forest disturbance rates and composition influenced by changing ownerships, conservation easements, and land certification? Forest Science, 58(2), 119-129. https://doi.org/10.5849/forsci.10-041

Pettorelli, N., Vik, J. O., Mysterud., A., Gaillard, J. M., Tucker, C. J., \& Stenseth, N. C. (2005). Using the satellite-derived NDVI to assess ecological responses to environmental change. Trends in Ecology \& Evolution, 21(1), 503-510. https://doi.org/10.1016/j.tree.2005.05.011

Randle, A., Barlow, B., \& Gunnoe, A. (2015). Southern forest in flux: mapping changing timberland ownership in five Alabama counties. Southeastern Geographer, 55(4), 459-473. https://doi.org/10.1353/sgo.2015.0028

Rouse, J. W., Haas, R. H., Schell, J. A., \& Deering, D. W. (1973). Monitoring vegetation systems in the Great Plains with ERTS. In 3rd ERTS Symposium, NASA SP-351.309-317.

Silver, E. J., Leahy, J. E., Weiskittel, A. R., Noblet, C. L., \& Kittredge, D. B. (2015). An evidence-based review of timber harvesting behavior among private woodland owners. Journal of Forestry, 113(5), 490-499. https://doi.org/10.5849/jof.14-089

Singh, A. (1989). Digital change detection techniques using remotely-sensed data. International Journal of Remote Sensing, 10, 989-1003. https://doi.org/10.1080/01431168908903939

Smith, W. B., Miles, P. D., Vissage, J. S., \& Pugh, S. A. (2004). Forest resources of the United States, 2002. US Forest Service. General Technical Report NC-241, Northern Research Station. St. Paul, MN. 137 pp. https://doi.org/10.2737/NC-GTR-241

Stein, B. A. (2002). States of the Union: Ranking America's biodiversity. NatureServe. Arlington, Va. Retrieved August 4, 2014, from http://www.natureserve.org/library/stateofunions.pdf

Stein, P. R. (2011). Trends in forestland ownership and conservation. Forest History Today. Fall 2011:83-86.

Turner, M. G., Wear, D. N., \& Flamm, R. O. (1996). Land ownership and land-cover change in the Southern Appalachian Highlands and the Olympic Peninsula. Ecological Applications, 6(4), 1150-1172. https://doi.org/10.2307/2269599

USDA Forest Service. (1988). The South's fourth forest: alternatives for the future. Resource Report 24. Washington, DC. 529 pp.

USGS. (2015). Landsat 8 (L8) Data Users Handbook, 2015, LSDS-1574, verison 1.0. USGS EROS, Sioux Falls, USA. Available at: http://landsat.usgs.gov/documents/Landsat8DataUsersHandbook.pdf Accessed on February 3, 2015.

Vogelman, J. E., Howard, S. M., Yang, L., Larson, C. R., Wylie, B. K., \& Van Driel, J. N. (2001). Completion of the 1990's National land cover data set for the conterminous United States. Photogrammetric Engineering and Remote Sensing, 67, 650-662.

Wear, D. N., Carter, D., \& Prestemon, J. (2007). The US South's Timber Sector in 2005: A prospective analysis of recent change. USDA Forest Service, General Technical Report, SRS-99. Southern Research Station. Asheville, NC. 29 pp.

Wilson, E. H., \& Sader, S. A. (2002). Detection of forest harvest type using multiple dates of Landsat TM imagery. Remote Sensing of Environment, 80, 285-396. https://doi.org/10.1016/S0034-4257(01)00318-2

Zhang, D., Butler, B. J., \& Nagubadi, R. V. (2012). Institutional Timberland Ownership in the US South: Magnitude, Location, Dynamics, and Management. Journal of Forestry, 110(7), 255-361. https://doi.org/10.5849/jof.12-015

\section{Copyrights}

Copyright for this article is retained by the author(s), with first publication rights granted to the journal.

This is an open-access article distributed under the terms and conditions of the Creative Commons Attribution license (http://creativecommons.org/licenses/by/4.0/). 